\title{
Sintering, Microstructure, and Dielectric Properties of Copper Borates for High Frequency LTCC Applications
}

\author{
Dorota Szwagierczak $^{1, *(\mathbb{D}}$, Beata Synkiewicz-Musialska ${ }^{1}$, Jan Kulawik ${ }^{1}\left(\mathbb{D}\right.$ and Norbert Pałka ${ }^{2} \mathbb{C}$ \\ 1 Łukasiewicz Research Network-Institute of Microelectronics and Photonics, Kraków Division, Zabłocie 39, \\ 30-701 Kraków, Poland; beata.synkiewicz.musialska@imif.lukasiewicz.gov.pl (B.S.-M.); \\ jan.kulawik@imif.lukasiewicz.gov.pl (J.K.) \\ 2 Institute of Optoelectronics, Military University of Technology, ul. gen. S. Kaliskiego 2, \\ 00-908 Warszawa, Poland; norbert.palka@wat.edu.pl \\ * Correspondence: dorota.szwagierczak@imif.lukasiewicz.gov.pl
}

check for updates

Citation: Szwagierczak, D.;

Synkiewicz-Musialska, B.; Kulawik, J.; Pałka, N. Sintering, Microstructure, and Dielectric Properties of Copper Borates for High Frequency LTCC Applications. Materials 2021, 14, 4017. https://doi.org/10.3390/ma14144017

Academic Editor: Albena Paskaleva

Received: 10 June 2021

Accepted: 13 July 2021

Published: 18 July 2021

Publisher's Note: MDPI stays neutral with regard to jurisdictional claims in published maps and institutional affiliations.

Copyright: (c) 2021 by the authors. Licensee MDPI, Basel, Switzerland. This article is an open access article distributed under the terms and conditions of the Creative Commons Attribution (CC BY) license (https:// creativecommons.org/licenses/by/ $4.0 /)$.

\begin{abstract}
New ceramic materials based on two copper borates, $\mathrm{CuB}_{2} \mathrm{O}_{4}$ and $\mathrm{Cu}_{3} \mathrm{~B}_{2} \mathrm{O}_{6}$, were prepared via solid state synthesis and sintering, and characterized as promising candidates for low dielectric permittivity substrates for very high frequency circuits. The sintering behavior, composition, microstructure, and dielectric properties of the ceramics were investigated using a heating microscope, X-ray diffractometry, scanning electron microscopy, energy dispersive spectroscopy, and terahertz time domain spectroscopy. The studies revealed a low dielectric permittivity of 5.1-6.7 and low dielectric loss in the frequency range $0.14-0.7 \mathrm{THz}$. The copper borate-based materials, owing to a low sintering temperature of $900-960{ }^{\circ} \mathrm{C}$, are suitable for LTCC (low temperature cofired ceramics) applications.
\end{abstract}

Keywords: microelectronics; packaging; copper borates; ceramic substrates; low dielectric permittivity; dielectric properties; THz spectroscopy; LTCC applications

\section{Introduction}

Modern high frequency communication systems create demand for new substrate materials with specific dielectric characteristics comprising a low dielectric permittivity, a low dielectric loss, and a low temperature coefficient of dielectric permittivity. Such dielectric properties of a substrate for microwave and mm-wave circuits improve the signal speed and quality, selectivity, and temperature stability of the operating frequency [1-5].

Silicates, such as cordierite, forsterite, diopside, mullite, and willemite, are wellknown conventional materials for low dielectric permittivity substrates for microwave circuits [6-12]. Recently, with the tendency to decrease the sintering temperature, new materials have attracted more attention. Besides molybdates, tungstates, and phosphates, some borates are good candidates for new materials with a low sintering temperature [13-24].

The copper metaborate $\mathrm{CuB}_{2} \mathrm{O}_{4}$ crystallizes in a tetragonal structure with $\mathrm{I}-42 \mathrm{~d}$ space group [25-27]. Its structure is composed of a $\mathrm{BO}_{4}$ tetrahedra sharing four common oxygen ions. $\mathrm{Cu}^{2+}$ ions are situated between them in two different crystallographic positions corresponding to a planar square or an elongated octahedral coordination [25-27].

$\mathrm{Cu}_{3} \mathrm{~B}_{2} \mathrm{O}_{6}$ has a more complex structure and a lower symmetry [28] as compared with $\mathrm{CuB}_{2} \mathrm{O}_{4}$. The best known is $\mathrm{Cu}_{3} \mathrm{~B}_{2} \mathrm{O}_{6}$ with a triclinic structure, although the crystallization of this compound in the monoclinic and orthorhombic structures was also reported. In $\mathrm{Cu}_{3} \mathrm{~B}_{2} \mathrm{O}_{6}, \mathrm{Cu}^{2+}$ ions occupy 16 nonequivalent crystallographic positions, which can be divided into the following three types-predominant square planar positions $\left(\mathrm{CuO}_{4}\right)$ with the coordination number four, distorted square pyramids $\left(\mathrm{CuO}_{5}\right)$ with the coordination number five, and distorted octahedral positions $\left(\mathrm{CuO}_{6}\right)$ with the coordination number six. For this compound, the calculated average effective coordination number is close to four for the triclinic structure. In $\mathrm{Cu}_{3} \mathrm{~B}_{2} \mathrm{O}_{6}$, boron also shows different coordination 
numbers- $\left(\mathrm{BO}_{3}\right)$ and $\left(\mathrm{B}_{2} \mathrm{O}_{5}\right)$ groups occur with shorter $\mathrm{B}-\mathrm{O}$ bonds than for tetrahedral $\left(\mathrm{BO}_{4}\right)$ groups in $\mathrm{CuB}_{2} \mathrm{O}_{4}$ [28].

Besides broad studies of the magnetic properties of $\mathrm{CuB}_{2} \mathrm{O}_{4}$ and $\mathrm{Cu}_{3} \mathrm{~B}_{2} \mathrm{O}_{6}$ crystals, potential magneto-optical, piezoelectric, multiferroic, and photocatalytic applications of $\mathrm{CuB}_{2} \mathrm{O}_{4}$ were also reported [25-27,29-37]. Furthermore, $\mathrm{Cu}_{3} \mathrm{~B}_{2} \mathrm{O}_{6}$ was applied for active electrodes of lithium-ion batteries [38,39]. However, the characterization of dielectric properties at $\mathrm{THz}$ frequencies for ceramic substrates made of copper borates has remained an unexplored area thus far.

This work reports on sintering behavior, microstructure, and dielectric properties in the $\mathrm{THz}$ range of new ceramics based on two pure copper borates, $\mathrm{CuB}_{2} \mathrm{O}_{4}$ and $\mathrm{Cu}_{3} \mathrm{~B}_{2} \mathrm{O}_{6}$, and $\mathrm{CuB}_{2} \mathrm{O}_{4}-\mathrm{Cu}_{3} \mathrm{~B}_{2} \mathrm{O}_{6}$ mixtures. These ceramics offer a low dielectric permittivity and a low dielectric loss at very high frequencies, and a relatively low sintering temperature adequate for LTCC (low temperature cofired ceramics) technology.

\section{Materials and Methods}

Two copper borates, $\mathrm{CuB}_{2} \mathrm{O}_{4}$ and $\mathrm{Cu}_{3} \mathrm{~B}_{2} \mathrm{O}_{6}$, were synthesized using the conventional solid state reaction method. The high purity starting materials, $\mathrm{H}_{3} \mathrm{BO}_{3}$ and $\mathrm{CuO}$ (Sigma Aldrich, St. Louis, MO, USA), were mixed in stoichiometric proportions, ball milled (Pulverisette 5, Fritsch, Germany) for $8 \mathrm{~h}$ in isopropyl alcohol, and dried. Then, the powders were pressed into pellets and calcined in a two-step process-at $200-400{ }^{\circ} \mathrm{C}$ for $2 \mathrm{~h}$ to decompose boric acid, and at $700{ }^{\circ} \mathrm{C}$ for $5 \mathrm{~h}$ to carry out solid state syntheses.

The resulting materials were ball milled for $8 \mathrm{~h}$ to obtain fine $\mathrm{CuB}_{2} \mathrm{O}_{4}$ and $\mathrm{Cu}_{3} \mathrm{~B}_{2} \mathrm{O}_{6}$ powders. In addition, three $\mathrm{CuB}_{2} \mathrm{O}_{4}-\mathrm{Cu}_{3} \mathrm{~B}_{2} \mathrm{O}_{6}$ mixtures containing 35, 50, and $70 \mathrm{wt} . \%$ $\mathrm{Cu}_{3} \mathrm{~B}_{2} \mathrm{O}_{6}$ were prepared by ball milling for $8 \mathrm{~h}$. For the last two compositions, $5 \mathrm{wt} . \%$ $\mathrm{CuBi}_{2} \mathrm{O}_{4}$ was added as a sintering aid. Finally, the powders were granulated with polyvinyl alcohol, pressed into pellets, and sintered in the temperature range $900-960{ }^{\circ} \mathrm{C}$.

The phase compositions of the materials were investigated using the $\mathrm{X}$-ray diffraction method (Empyrean, PANalytical, Almelo, The Netherlands) using $\mathrm{Cu} \mathrm{K}_{\alpha 1}$ radiation within a $2 \theta$ range of 10 to $90^{\circ}$. Optimal sintering conditions and melting points of the samples were established based on observations in a heating microscope (Leitz, Germany) in the temperature range $20-1040{ }^{\circ} \mathrm{C}$. Scanning electron microscopy and X-ray energy dispersive spectroscopy (FEI Nova Nano SEM 200 with EDAX Genesis EDS system, Hillsboro, OR, USA) were used to characterize the microstructure and elemental composition of the ceramics.

Dielectric properties at room temperature in the frequency range $0.12-2.5 \mathrm{THz}$ were studied using time domain spectroscopy (TDS) (TPS Spectra 3000, Teraview, Cambridge, UK) according to the procedure reported previously [12]. The measurements were performed in purged air to avoid interference related to the presence of water vapor.

\section{Results and Discussion}

\subsection{Phase Composition}

As illustrated in Figure 1a,b, the XRD phase analysis confirmed the presence of the planned copper borates $\mathrm{CuB}_{2} \mathrm{O}_{4}$ and $\mathrm{Cu}_{3} \mathrm{~B}_{2} \mathrm{O}_{6}$ as crystalline phases. $\mathrm{CuB}_{2} \mathrm{O}_{4}$ shows the tetragonal structure with the space group I-42, while $\mathrm{Cu}_{3} \mathrm{~B}_{2} \mathrm{O}_{6}$ was detected as triclinic $\mathrm{Cu}_{15} \mathrm{~B}_{10} \mathrm{O}_{30}$ with the space group P-1. For the compositions prepared as $\mathrm{CuB}_{2} \mathrm{O}_{4}-\mathrm{Cu}_{3} \mathrm{~B}_{2} \mathrm{O}_{6}$ mixtures with a $5 \% \mathrm{CuBi}_{2} \mathrm{O}_{4}$ addition, the $\mathrm{XRD}$ analysis revealed two main crystalline copper borate phases, but additional crystalline phases were not detected (Figure 1d). This implies that the sintering aid, $\mathrm{CuBi}_{2} \mathrm{O}_{4}$, formed an amorphous phase or entered the crystal lattice of the main crystalline components. 

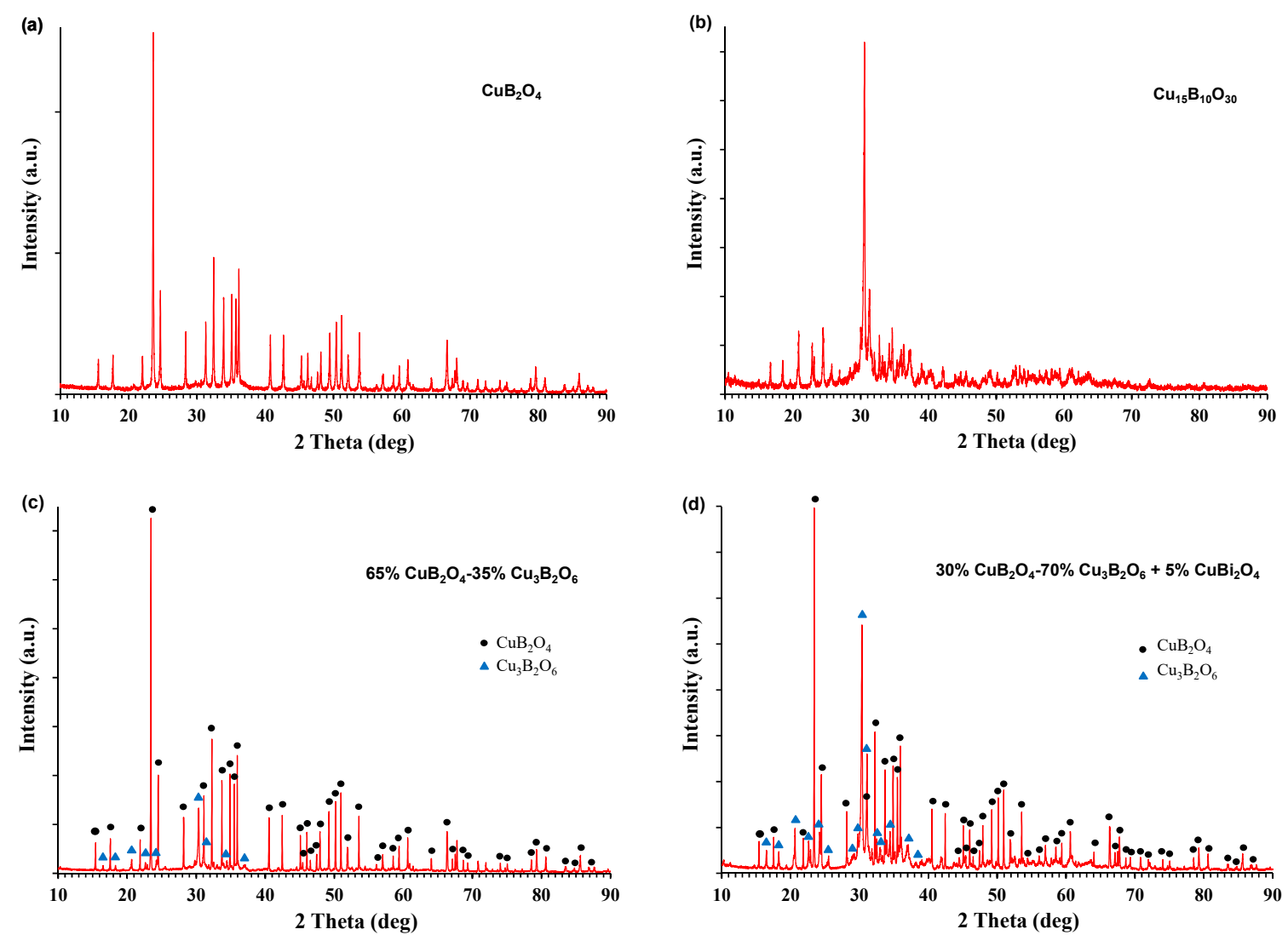

Figure 1. Diffraction patterns of the ceramics: (a) $\mathrm{CuB}_{2} \mathrm{O}_{4}$, (b) $\mathrm{Cu}_{3} \mathrm{~B}_{2} \mathrm{O}_{6}$, (c) $65 \% \mathrm{CuB}_{2} \mathrm{O}_{4}-35 \% \mathrm{Cu}_{3} \mathrm{~B}_{2} \mathrm{O}_{6}$, and (d) $30 \%$ $\mathrm{CuB}_{2} \mathrm{O}_{4}-70 \% \mathrm{Cu}_{3} \mathrm{~B}_{2} \mathrm{O}_{6}$ doped with $5 \% \mathrm{CuBi}_{2} \mathrm{O}_{4}$.

\subsection{Heating Microscope Studies}

Figure 2 presents some selected images from a heating microscope that provided insight into the behavior of the samples during heating from room temperature to $1040{ }^{\circ} \mathrm{C}$.
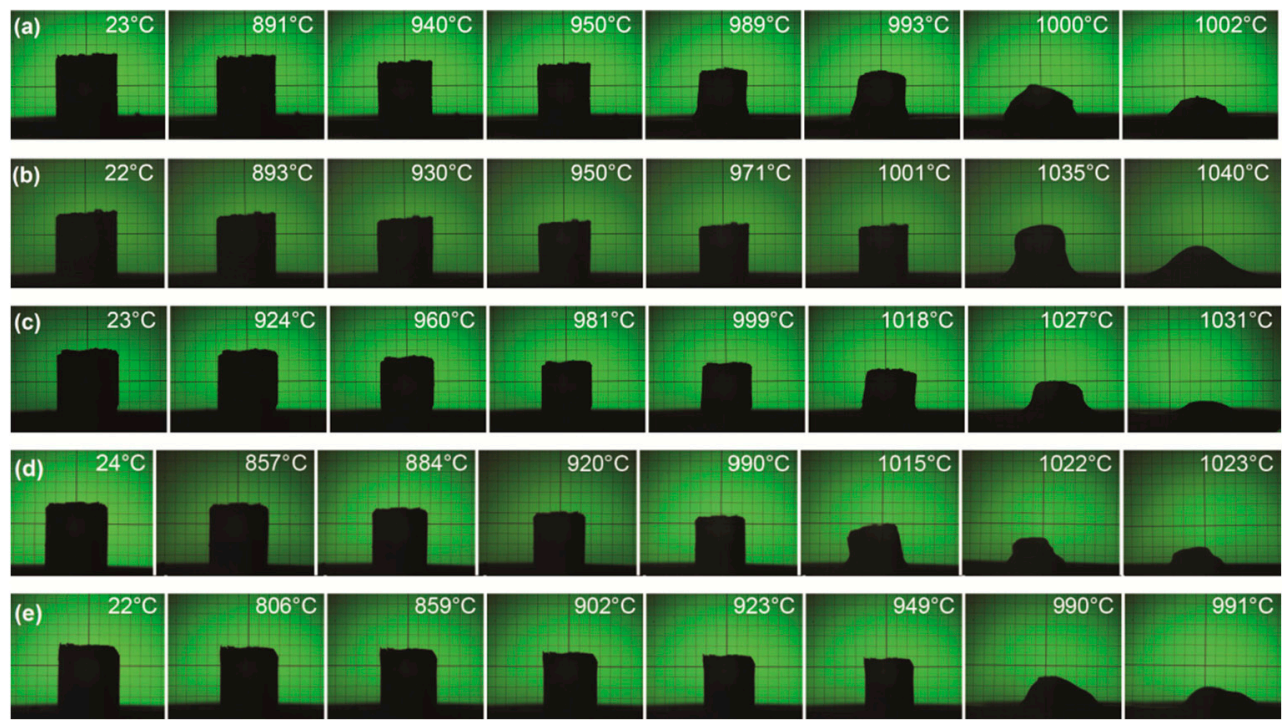

Figure 2. Selected images from a heating microscope for: (a) $\mathrm{CuB}_{2} \mathrm{O}_{4},(\mathbf{b}) \mathrm{Cu}_{3} \mathrm{~B}_{2} \mathrm{O}_{6}$, (c) $65 \% \mathrm{CuB}_{2} \mathrm{O}_{4}{ }^{-}$ $35 \% \mathrm{Cu}_{3} \mathrm{~B}_{2} \mathrm{O}_{6}$, (d) $50 \% \mathrm{CuB}_{2} \mathrm{O}_{4}-50 \% \mathrm{Cu}_{3} \mathrm{~B}_{2} \mathrm{O}_{6}$ doped with $5 \% \mathrm{CuBi}_{2} \mathrm{O}_{4}$, (e) $30 \% \mathrm{CuB}_{2} \mathrm{O}_{4}-70 \%$ $\mathrm{Cu}_{3} \mathrm{~B}_{2} \mathrm{O}_{6}$ doped with $5 \% \mathrm{CuBi}_{2} \mathrm{O}_{4}$. 
These studies helped to establish the optimal firing profiles for each composition based on information about the temperature range in which the shrinkage occurs and about the softening and melting points. For pure copper borates (Figure $2 a, b$ ), the samples start to shrink at 891 and $893{ }^{\circ} \mathrm{C}$, and the relevant optimal sintering temperatures are 940 and $930{ }^{\circ} \mathrm{C}$ for $\mathrm{CuB}_{2} \mathrm{O}_{4}$ and $\mathrm{Cu}_{3} \mathrm{~B}_{2} \mathrm{O}_{6}$, respectively. The melting points are $1000{ }^{\circ} \mathrm{C}$ for $\mathrm{CuB}_{2} \mathrm{O}_{4}$ and $1040{ }^{\circ} \mathrm{C}$ for $\mathrm{Cu}_{3} \mathrm{~B}_{2} \mathrm{O}_{6}$. The $\mathrm{Cu}_{3} \mathrm{~B}_{2} \mathrm{O}_{6}$ ceramic shows a higher melting point than $\mathrm{CuB}_{2} \mathrm{O}_{4}$, but it has a similar temperature of the shrinkage onset and exhibits an advantageous feature of a broader sintering range. Consequently, its optimal sintering temperature is close or even lower as compared with $\mathrm{CuB}_{2} \mathrm{O}_{4}$. For mixed copper borates, the optimal sintering temperatures were established as 960,920 , and $900{ }^{\circ} \mathrm{C}$ for $65 \% \mathrm{CuB}_{2} \mathrm{O}_{4}-35 \% \mathrm{Cu}_{3} \mathrm{~B}_{2} \mathrm{O}_{6}$, $50 \% \mathrm{CuB}_{2} \mathrm{O}_{4}-50 \% \mathrm{Cu}_{3} \mathrm{~B}_{2} \mathrm{O}_{6}$ with $5 \% \mathrm{CuBi}_{2} \mathrm{O}_{4}$, and $30 \% \mathrm{CuB}_{2} \mathrm{O}_{4}-70 \% \mathrm{Cu}_{3} \mathrm{~B}_{2} \mathrm{O}_{6}$ with $5 \%$ $\mathrm{CuBi}_{2} \mathrm{O}_{4}$, respectively.

\subsection{Microstructural Studies}

The SEM studies of all the sintered samples based on pure and mixed copper borates showed a very compact microstructure with a small contribution of porosity. It follows from the comparison of the images in Figure $3 a, b$ that the microstructure for pure copper borates is similar, fine-grained, and uniform, with grain sizes in the $0.5-3 \mu \mathrm{m}$ range.
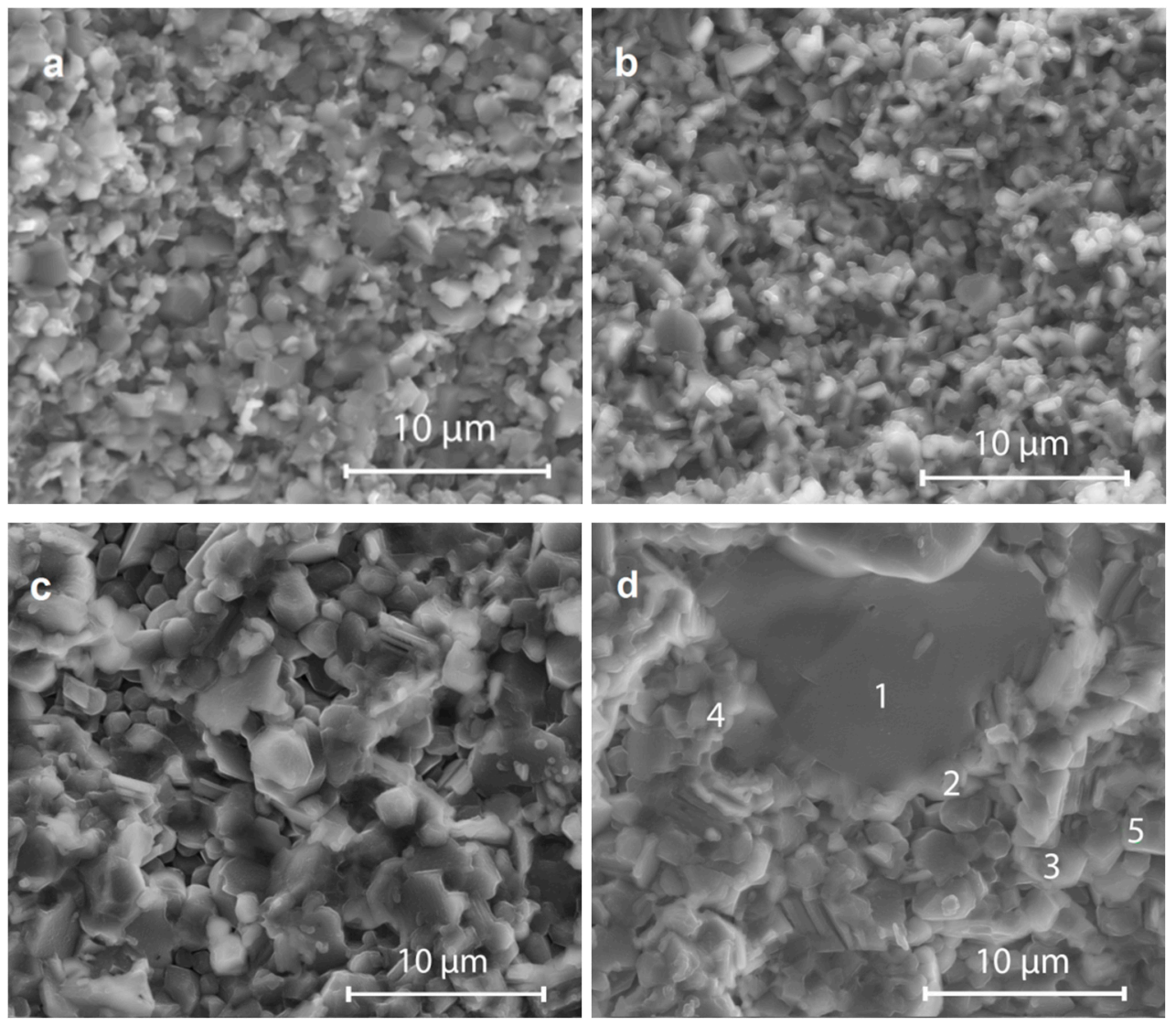

Figure 3. SEM images of fractured cross-sections of ceramic samples: (a) $\mathrm{CuB}_{2} \mathrm{O}_{4}$ sintered at $940{ }^{\circ} \mathrm{C}$, (b) $\mathrm{Cu}_{3} \mathrm{~B}_{2} \mathrm{O}_{6}$ sintered at $930{ }^{\circ} \mathrm{C}$, (c) $50 \% \mathrm{CuB}_{2} \mathrm{O}_{4}-50 \% \mathrm{Cu}_{3} \mathrm{~B}_{2} \mathrm{O}_{6}$ doped with $5 \% \mathrm{CuBi}_{2} \mathrm{O}_{4}$ sintered at $920{ }^{\circ} \mathrm{C}$, and (d) $30 \% \mathrm{CuB}_{2} \mathrm{O}_{4}-70 \% \mathrm{Cu}_{3} \mathrm{~B}_{2} \mathrm{O}_{6}$ doped with $5 \% \mathrm{CuBi}_{2} \mathrm{O}_{4}$ sintered at $900{ }^{\circ} \mathrm{C}, \times 10,000$.

For the mixed borates compositions, the dense microstructure was preserved, although there was a more significant variation in grain sizes as compared with the single-phase copper borate ceramics. For the ceramics with $5 \% \mathrm{CuBi}_{2} \mathrm{O}_{4}$ added (Figure $3 \mathrm{c}, \mathrm{d}$ ), small grains 1-3 $\mu \mathrm{m}$ in diameter prevail, although a fraction of much bigger grains appears with sizes ranging from 4 to $12 \mu \mathrm{m}$. Thus, it seems that the sintering aid causes a grain growth effect, even though the sintering temperature is slightly lower as compared with 
pure copper borates. Table 1 presents the results of the EDS analysis at the points marked in Figure $3 \mathrm{~d}$ for $30 \% \mathrm{CuB}_{2} \mathrm{O}_{4}-70 \% \mathrm{Cu}_{3} \mathrm{~B}_{2} \mathrm{O}_{6}$ ceramic doped with $5 \% \mathrm{CuBi}_{2} \mathrm{O}_{4}$. Point one represents a big grain attributed to $\mathrm{CuB}_{2} \mathrm{O}_{4}(\mathrm{Cu} / \mathrm{B}$ ratio close to 0.5$)$, while points two, four, and five were assigned to smaller grains of $\mathrm{Cu}_{3} \mathrm{~B}_{2} \mathrm{O}_{6}(\mathrm{Cu} / \mathrm{B}$ ratio close to 1.5). Grain boundaries were enriched with $\mathrm{Bi}$ originating from the dopant $\mathrm{CuBi}_{2} \mathrm{O}_{4}$ (point three). The EDS results are distorted due to the imprecise detection of boron using this method.

Table 1. Results of EDS analysis at the points marked in Figure $3 \mathrm{~d}$ for $30 \% \mathrm{CuB}_{2} \mathrm{O}_{4}-70 \% \mathrm{Cu}_{3} \mathrm{~B}_{2} \mathrm{O}_{6}$ ceramic doped with $5 \% \mathrm{CuBi}_{2} \mathrm{O}_{4}$, sintered at $900{ }^{\circ} \mathrm{C}$.

\begin{tabular}{cccccc}
\hline \multirow{2}{*}{ Element } & \multicolumn{5}{c}{ at. \% } \\
\cline { 2 - 6 } & Point 1 & Point 2 & Point 3 & Point 4 & Point 5 \\
\hline $\mathrm{B}$ & 45.76 & 26.06 & 28.20 & 31.63 & 26.31 \\
\hline $\mathrm{O}$ & 31.40 & 16.75 & 25.15 & 26.65 & 17.11 \\
\hline $\mathrm{Bi}$ & 0.20 & 0.62 & 0.92 & 0.47 & 0.74 \\
\hline $\mathrm{Cu}$ & 22.64 & 56.57 & 45.73 & 41.25 & 55.84 \\
\hline $\mathrm{Cu} / \mathrm{B}$ & 0.49 & 2.17 & 1.62 & 1.30 & 2.12 \\
\hline
\end{tabular}

\subsection{Dielectric Properties}

A theoretical prediction of dielectric permittivity based on the knowledge about the composition and crystal structure of the compound should be considered to design a substrate material with dielectric properties tailored for high frequency applications. For a simple assessment of the real part of relative dielectric permittivity $\varepsilon_{r}$, one can use the Clausius-Mossotti equation, which relates this quantity with the polarizability $\alpha$ :

$$
\alpha=4 \pi \mathrm{V}_{\mathrm{m}} / 3\left[\left(\varepsilon_{\mathrm{r}}-1\right)\left(\varepsilon_{\mathrm{r}}+2\right)\right]
$$

where $V_{m}$ is the molar volume.

For a compound, molecular polarizability can be calculated using the additive rule, as a sum of the polarizabilities of particular ions that built the molecule. Thus, the molecular polarizabilities of the investigated copper borates can be expressed as follows:

$$
\begin{gathered}
\alpha\left(\mathrm{CuB}_{2} \mathrm{O}_{4}\right)=\alpha\left(\mathrm{Cu}^{2+}\right)+2 \alpha\left(\mathrm{B}^{3+}\right)+4 \alpha\left(\mathrm{O}^{2-}\right) \\
\alpha\left(\mathrm{Cu}_{3} \mathrm{~B}_{2} \mathrm{O}_{6}\right)=3 \alpha\left(\mathrm{Cu}^{2+}\right)+2 \alpha\left(\mathrm{B}^{3+}\right)+6 \alpha\left(\mathrm{O}^{2-}\right)
\end{gathered}
$$

The polarizabilities of the constituent ions are 2.11, 0.05, and $2.01 \AA^{3}$ for $\mathrm{Cu}^{2+}, \mathrm{B}^{3+}$, and $\mathrm{O}^{2-}$, respectively [40]. The molar volumes (calculated as the unit cell volume per the number of formula units in the unit cell) are 61.76 and $112.54 \AA^{3}$ for $\mathrm{CuB}_{2} \mathrm{O}_{4}$ and triclinic $\mathrm{Cu}_{3} \mathrm{~B}_{2} \mathrm{O}_{6}$, respectively. Thus, the theoretical relative dielectric permittivities of $\mathrm{CuB}_{2} \mathrm{O}_{4}$ and $\mathrm{Cu}_{3} \mathrm{~B}_{2} \mathrm{O}_{6}$ calculated from the Clausius-Mossotti equation are 7.83 and 7.61, respectively. These values are close to each other.

However, the predictions based on the Clausius-Mossotti relationship are consistent with the experimentally measured values mainly for a high symmetry cubic crystallographic system. For the materials characterized by structural peculiarities related to the presence of "rattling" or "compressed" cations, ionic or electronic conductivity, dipolar impurities, or piezoelectric behavior, distinct deviations from the additivity rule were observed [40].

Low polarizability is responsible for confining ionic polarization in a material. A lower average bond length diminishes the rattling effect of cations in a polyhedral structural unit. A lower cell volume restricts the interaction of polarizable dipoles [41-43]. Qin et al. [41] proposed a universal model based on machine learning for predicting microwave dielectric permittivity. These authors stated that there are three most important features related to the crystal structure of a compound determining its dielectric permittivity. According to 
this model, the dielectric permittivity decreases with a decrease in the polarizability per unit cell volume $p p v$ and with a decrease in the average bond length $\mathrm{blm}$. The average cell volume per atom $v a$ is also an important parameter that should be maintained in an optimal range. Qin et al. [41] stated that the ranges of the decisive parameters that favor creating materials with a low dielectric permittivity are $p p m<0.15$, va $11-16 \AA^{3}$, and $b l m<2.3 \AA$.

The relevant values for $\mathrm{CuB}_{2} \mathrm{O}_{4}$ and $\mathrm{Cu}_{3} \mathrm{~B}_{2} \mathrm{O}_{6}$ obtained in this work are 0.17 and 0.16 for ppm, and 17.6 and 10.2 for $v a$, respectively. The bond lengths reported for $\mathrm{CuB}_{2} \mathrm{O}_{4}$ are $1.999 \AA$ for prevailing $\mathrm{Cu}-\mathrm{O}$ shorter bonds, $2.864 \AA$ for $\mathrm{Cu}-\mathrm{O}$ longer bonds, and 1.444-1.487 $\AA$ for $\mathrm{B}-\mathrm{O}$ bonds [26]. For $\mathrm{Cu}_{3} \mathrm{~B}_{2} \mathrm{O}_{6}$, the average $\mathrm{Cu}-\mathrm{O}$ bond length is $2.1 \AA$ [28]. The analysis of $p p m, v a$, and $b l m$ values for $\mathrm{CuB}_{2} \mathrm{O}_{4}$ and $\mathrm{Cu}_{3} \mathrm{~B}_{2} \mathrm{O}_{6}$ leads to the conclusion that these parameters are close to the ranges indicated in [41] for low permittivity candidate materials.

Figure $4 \mathrm{a}, \mathrm{b}$ compare the frequency dependences of the dielectric permittivities and the dissipation factors of copper borate ceramics at $20^{\circ} \mathrm{C}$ in the $0.12-2.5 \mathrm{THz}$ range.
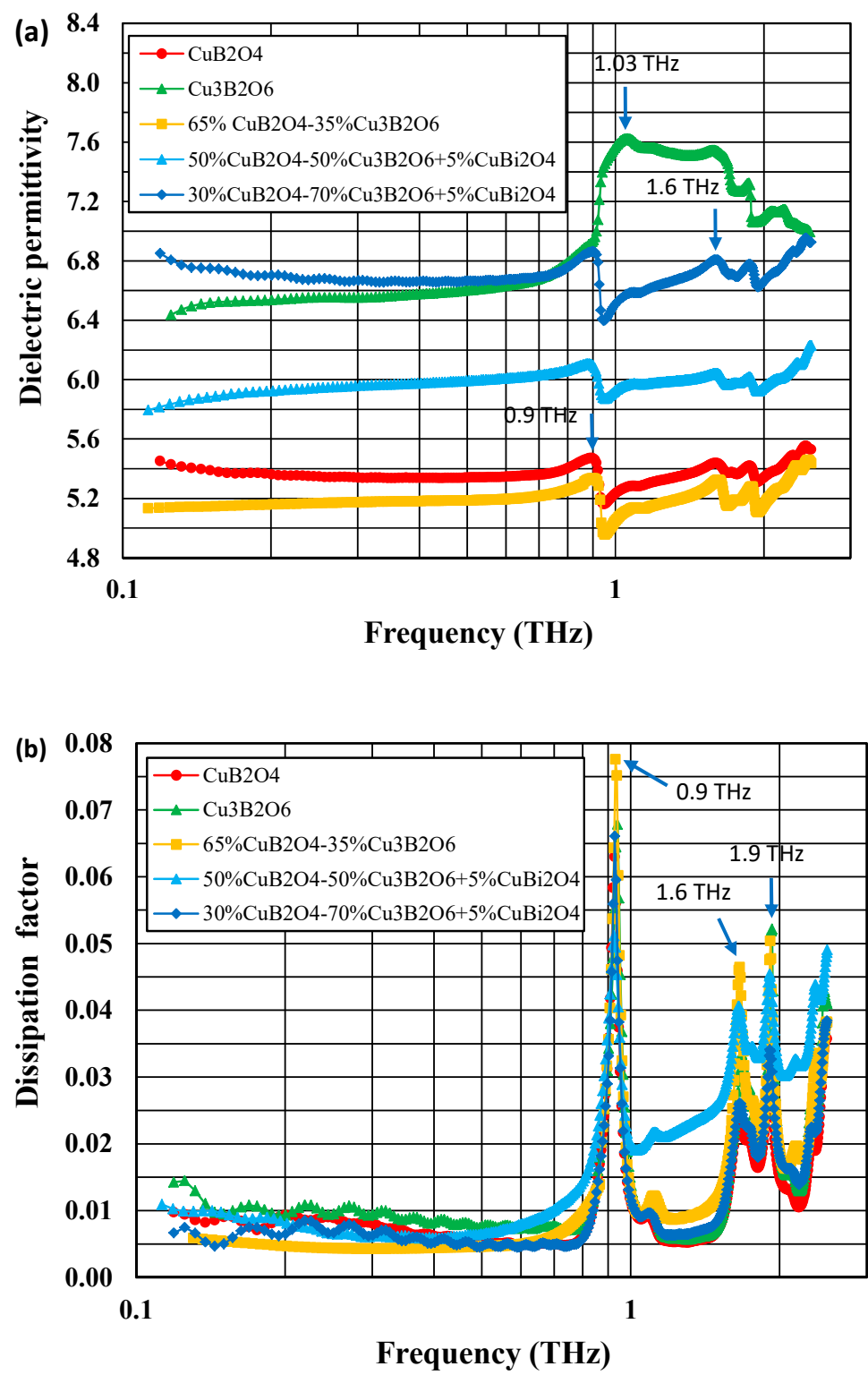

Figure 4. Comparison of dielectric permittivity (a) and dissipation factor (b) at $20^{\circ} \mathrm{C}$ as a function of frequency in the range $0.12-2.5 \mathrm{THz}$ for $\mathrm{CuB}_{2} \mathrm{O}_{4}, \mathrm{Cu}_{3} \mathrm{~B}_{2} \mathrm{O}_{6}$, and $\mathrm{CuB}_{2} \mathrm{O}_{4}-\mathrm{Cu}_{3} \mathrm{~B}_{2} \mathrm{O}_{6}$ ceramics. 
In the 0.14-0.7 THz range, the dielectric permittivities are low, at a level of 5.3-5.4 for $\mathrm{CuB}_{2} \mathrm{O}_{4}, 6.4-6.7$ for $\mathrm{Cu}_{3} \mathrm{~B}_{2} \mathrm{O}_{6}, 5.1-5.2$ for $65 \% \mathrm{CuB}_{2} \mathrm{O}_{4-} 35 \% \mathrm{Cu}_{3} \mathrm{~B}_{2} \mathrm{O}_{6}, 5.8-6.0$ for $50 \%$ $\mathrm{CuB}_{2} \mathrm{O}_{4-} 50 \% \mathrm{Cu}_{3} \mathrm{~B}_{2} \mathrm{O}_{6}$ with $5 \% \mathrm{CuBi}_{2} \mathrm{O}_{4}$, and 5.8-6.1 for $30 \% \mathrm{CuB}_{2} \mathrm{O}_{4-} 70 \% \mathrm{Cu}_{3} \mathrm{~B}_{2} \mathrm{O}_{6}$ with $5 \% \mathrm{CuBi}_{2} \mathrm{O}_{4}$. The lowest dielectric permittivities were shown by pure $\mathrm{CuB}_{2} \mathrm{O}_{4}$ ceramic and $65 \% \mathrm{CuB}_{2} \mathrm{O}_{4-} 35 \% \mathrm{Cu}_{3} \mathrm{~B}_{2} \mathrm{O}_{6}$ ceramic without the sintering aid. For all the materials under investigation, the dielectric permittivity changes very slightly with a frequency up to $0.7 \mathrm{THz}$ and then reaches a maximum at about $1 \mathrm{THz}$ for $\mathrm{Cu}_{3} \mathrm{~B}_{2} \mathrm{O}_{6}$ and at about $0.9 \mathrm{THz}$ for the rest of the copper borate-based ceramics.

Figure $5 \mathrm{a}, \mathrm{b}$ show the comparison of the dielectric permittivities and dissipation factors of the $\mathrm{CuB}_{2} \mathrm{O}_{4}$ ceramics sintered at three different temperatures-930, 940, and $950{ }^{\circ} \mathrm{C}$. The dielectric permittivity increases, while the dissipation factor decreases with an increasing sintering temperature. This is typical behavior that can be attributed to a lower porosity of the samples sintered at higher temperatures.
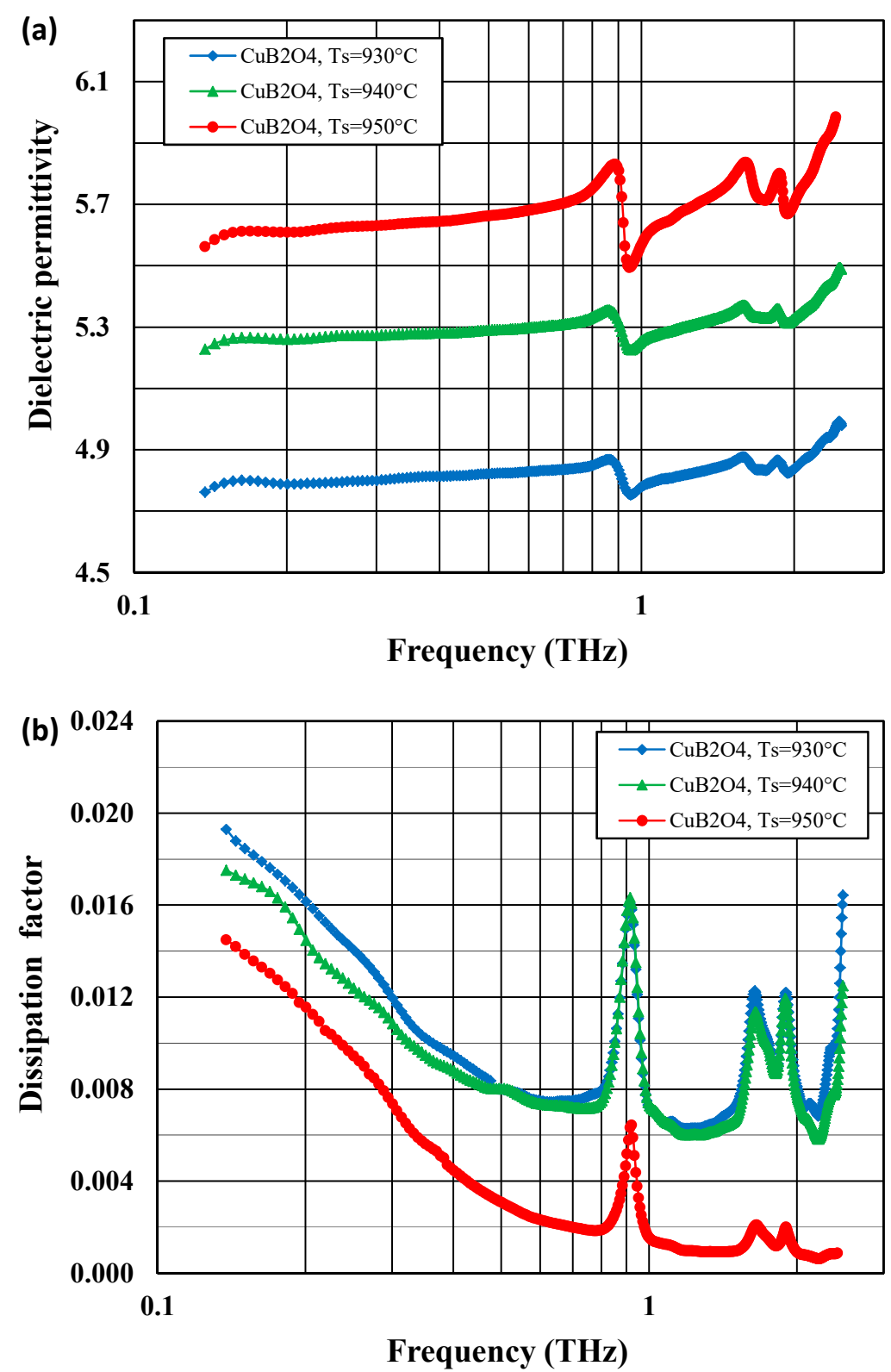

Figure 5. Comparison of dielectric permittivity (a) and dissipation factor (b) versus frequency in the range $0.12-2.5 \mathrm{THz}$ for $\mathrm{CuB}_{2} \mathrm{O}_{4}$ ceramics sintered at 930,940 , and $950{ }^{\circ} \mathrm{C}$. 
The dissipation factors are relatively low $(0.004-0.01)$ in the $0.14-0.7 \mathrm{THz}$ range, with a flat minimum at $0.4-0.6 \mathrm{THz}$. A few peaks on the dissipation factor versus frequency plots were observed above $0.9 \mathrm{THz}$ at the positions corresponding to those of the dielectric permittivity maxima.

At very high $\mathrm{THz}$ frequencies, some types of dielectric polarization, such as space charge and dipolar polarizations, cannot follow the changes of the external electrical field. In this case, the dielectric behavior is determined by ionic, atomic, and electronic polarization. The dielectric properties can be described by the damped harmonic oscillators model [44]. This model explains the observed frequency independent constant value of the real part of dielectric permittivity $\varepsilon^{\prime}$, an increase in its imaginary part $\varepsilon^{\prime \prime}$ and, consequently, the dissipation factor $\left(\varepsilon^{\prime \prime} / \varepsilon^{\prime}\right)$ in the region of $\mathrm{THz}$ frequencies.

Peaks on the dielectric permittivity/dissipation factor versus frequency plots that occur above $0.7 \mathrm{THz}$ are supposed to be attributed to phonon modes related to vibrations in $\mathrm{Cu}-\mathrm{O}$ complexes [26,28]. Due to the large number of atoms that form the unit cells of both copper borates (42 atoms for $\mathrm{CuB}_{2} \mathrm{O}_{4}, 110$ atoms for $\mathrm{Cu}_{3} \mathrm{~B}_{2} \mathrm{O}_{6}[26,28]$ ), phonon modes for these compounds are numerous, which was confirmed using infrared and Raman spectroscopic studies [26-29].

In Figure $6 \mathrm{a}, \mathrm{b}$, the dielectric permittivities and dissipation factors for a few frequencies in the $0.2-0.7 \mathrm{~Hz}$ range (the region of a weak frequency dependence) are plotted as a function of temperature in the range $30-150{ }^{\circ} \mathrm{C}$ for the $\mathrm{CuB}_{2} \mathrm{O}_{4}$ ceramic. The temperature dependence of dielectric permittivity is very weak up to $90{ }^{\circ} \mathrm{C}$, while the dissipation factor is almost temperature independent in the whole analyzed range. The frequencies corresponding to the peaks of dielectric permittivity and dissipation factor do not change with temperature, which implies that the phenomena responsible for these peaks are not thermally activated processes. It was found that the temperature coefficient of dielectric permittivity of $\mathrm{CuB}_{2} \mathrm{O}_{4}$ ceramic in the temperature range $30-90{ }^{\circ} \mathrm{C}$ is negative and changes from -19 to $-55 \mathrm{ppm} /{ }^{\circ} \mathrm{C}$ in the $0.2-0.7 \mathrm{THz}$ range.
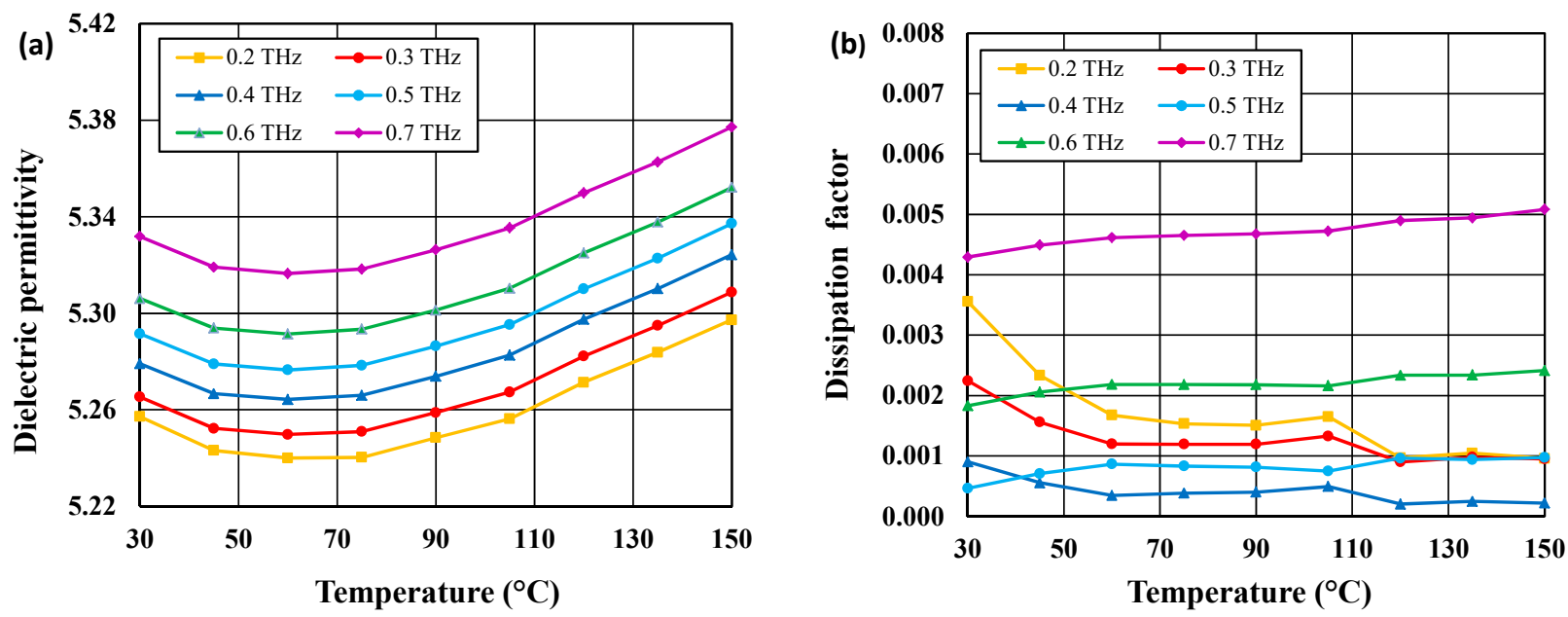

Figure 6. Comparison of dielectric permittivity (a) and dissipation factor (b) of $\mathrm{CuB}_{2} \mathrm{O}_{4}$ ceramic sintered at $940{ }^{\circ} \mathrm{C}$ as a function of temperature in the range $30-150{ }^{\circ} \mathrm{C}$ for a few frequencies in the $0.2-0.7 \mathrm{THz}$ range.

The dielectric permittivities determined experimentally in this work are distinctly lower than those calculated using the Clausius-Mossotti equation. This discrepancy cannot be assigned only to porosity, considering the high relative density of the sintered samples at a level of $95-98 \%$. It is supposed to be related to the complex noncentrosymmetric crystallographic structures of the copper borates under investigation. For such systems, deviations from the Clausius-Mossotti relationship have often been observed [40].

For commercially available LTCC materials, the values of dielectric permittivity in the range $4-7$ and $\tan \delta$ below 0.012 at $1 \mathrm{THz}$ are considered low values, suitable for millimeter 
wave systems. The dielectric properties of $\mathrm{CuB}_{2} \mathrm{O}_{4}$ and $\mathrm{CuB}_{2} \mathrm{O}_{4}-\mathrm{Cu}_{3} \mathrm{~B}_{2} \mathrm{O}_{6}$ ceramics in the 0.14-0.7 THz range are comparable with those reported for the commercial LTCC material Ferro $\mathrm{A} 6 \mathrm{M}$ at $1 \mathrm{THz}\left(\varepsilon_{r}{ }^{\prime}=6.06, \tan \delta=0.012\right)$ [45]. We plan to use the developed powders based on copper borates for tape casting and the fabrication of multilayer LTCC substrates appropriate for very high frequency applications in future work.

\section{Conclusions}

New ceramics based on two copper borates, $\mathrm{CuB}_{2} \mathrm{O}_{4}$ and $\mathrm{Cu}_{3} \mathrm{~B}_{2} \mathrm{O}_{6}$, were successfully prepared via solid state synthesis and sintering processes. These ceramics exhibit the following advantageous features: a low sintering temperature suitable for LTCC technology, a very dense microstructure, a low and temperature stable dielectric permittivity (5.1-6.7), and a low dielectric loss $(0.004-0.01)$ in the $0.14-0.7 \mathrm{THz}$ range. The developed ceramics are promising substrate materials for submillimeter wave applications and have been investigated for the first time in such a frequency range.

Author Contributions: Conceptualization, D.S.; data curation, B.S.-M.; formal analysis, D.S., B.S.-M., and N.P.; funding acquisition, D.S.; investigation, D.S., B.S.-M., J.K., and N.P.; methodology, B.S.-M., J.K., and N.P.; project administration, D.S.; resources, J.K.; supervision, D.S.; validation, D.S. and N.P.; visualization, B.S.-M.; writing—original draft, D.S.; writing—review and editing, D.S. and N.P. All authors have read and agreed to the published version of the manuscript.

Funding: This research was funded by the NATIONAL SCIENCE CENTRE, Poland, grant number 2019/35/B/ST5/02674.

Institutional Review Board Statement: Not applicable.

Informed Consent Statement: Not applicable.

Data Availability Statement: The data presented in this study are available on request from the corresponding author. The data are not publicly available as the data also form part of an ongoing study.

Conflicts of Interest: The authors declare no conflict of interest. The funders had no role in the design of the study; in the collection, analyses, or interpretation of data; in the writing of the manuscript, or in the decision to publish the results.

\section{References}

1. Muhammad, R.; Iqbal, Y.; Rambo, C.R.; Khan, H. Research trends in microwave dielectrics and factors affecting their properties: A review. Int. J. Mater. Res. 2014, 105, 431-439. [CrossRef]

2. Raveendran, R.A.; Sebastian, M.T.; Raman, S. Applications of microwave materials: A review. J. Electron. Mater. 2019, 48, 2601-2634. [CrossRef]

3. Sebastian, M.T.; Ubic, R.; Jantunen, H. Low-loss dielectric ceramic materials and their properties. Int. Mater. Rev. 2015, 60, 392-412. [CrossRef]

4. Song, H.J. Packages for terahertz electronics. Proc. IEEE 2017, 105, 1121-1138. [CrossRef]

5. Rappaport, T.S.; Sun, S.; Mayzus, R.; Zhao, H.; Azar, Y.; Wang, K.; Wong, G.N.; Schulz, J.K.; Samimi, M.; Gutierrez, F. Millimeter wave mobile communications for 5G cellular: It will work! IEEE Access 2013, 1, 335-349. [CrossRef]

6. Tsunooka, T.; Ando, M.; Suzuki, S.; Yasufuku, Y.; Ohsato, H. Research \& developments for millimeter-wave dielectric forsterite with low dielectric constant, high Q, and zero temperature coefficient of resonant frequency. Jpn. J. Appl. Phys. 2013, 52, 09KH02. [CrossRef]

7. Bafrooei, H.B.; Liu, B.; Su, W.; Song, K.X. $\mathrm{Ca}_{3} \mathrm{MgSi}_{2} \mathrm{O}_{8}$ : Novel low-permittivity microwave dielectric ceramics for $5 \mathrm{G}$ application. Mater. Lett. 2020, 263, 127248. [CrossRef]

8. Szwagierczak, D.; Synkiewicz, B.; Kulawik, J. Low dielectric constant composites based on $\mathrm{B}_{2} \mathrm{O}_{3}$ and $\mathrm{SiO}_{2}$ rich glasses, cordierite and mullite. Ceram. Int. 2018, 44, 14495-14501. [CrossRef]

9. Lan, X.K.; Li, J.; Wang, F.; Wang, X.; Lu, W.Z.; Hu, M.Z.; Lei, W. A novel low permittivity $\operatorname{LiAl}_{0.98}\left(\mathrm{Zn}_{0.5} \mathrm{Si}_{0.5}\right)_{0.02} \mathrm{O}_{2}$ based microwave dielectric ceramics for LTCC application. Int. J. Appl. Ceram. Tech. 2020, 17, 745-750. [CrossRef]

10. Weng, Z.Z.; Song, C.X.; Xiong, Z.X.; Xue, H.; Sun, W.F.; Zhang, Y.; Yang, B.; Reece, M.J.; Yan, H.X. Microstructure and broadband dielectric properties of $\mathrm{Zn}_{2} \mathrm{SiO}_{4}$ ceramics with nano-sized $\mathrm{TiO}_{2}$ addition. Ceram. Int. 2019, 45, 13251-13256. [CrossRef]

11. $\mathrm{Hu}, \mathrm{X}$; Huang, X.J.; Chen, Y.H.; Li, Y.; Ling, Z.Y. Phase evolution and microwave dielectric properties of $\mathrm{SrTiO}_{3}$ added $\mathrm{ZnAl}_{2} \mathrm{O}_{4}$ $\mathrm{Zn}_{2} \mathrm{SiO}_{4}-\mathrm{SiO}_{2}$ ceramics. Ceram. Int. 2020, 46, 7050-7054. [CrossRef] 
12. Synkiewicz-Musialska, B.; Szwagierczak, D.; Kulawik, J.; Pałka, N.; Bajurko, P.R. Impact of additives and processing on microstructure and dielectric properties of willemite ceramics for LTCC terahertz applications. J. Eur. Ceram. Soc. 2020, 40, 362-370. [CrossRef]

13. Sasidharanpillai, A.; Kim, C.H.; Lee, C.H.; Sebastian, M.T.; Kim, H.T. Environmental friendly approach for the development of ultra-low firing $\mathrm{Li}_{2} \mathrm{WO}_{4}$ ceramic tapes. ACS Sustain. Chem. Eng. 2018, 6, 6849-6855. [CrossRef]

14. Yin, C.; Li, C.; Yang, G.; Fang, L.; Yuan, Y.; Shu, L.; Khaliq, J. $\mathrm{NaCa}_{4} \mathrm{~V}_{5} \mathrm{O}_{17}$ : A low-firing microwave dielectric ceramic with low permittivity and chemical compatibility with silver for LTCC applications. J. Eur. Ceram. Soc. 2020, 40, 386-390. [CrossRef]

15. Oliveira, R.G.M.; Silva, R.A.; de Morais, J.E.V.; Batista, G.S.; Silva, M.A.S.; Goes, J.C.E.; de Andrade, H.D.; Queiroz Júnior, I.S.; Singh, C.; Sombra, A.S.B. Effects of $\mathrm{CaTiO}_{3}$ addition on the microwave dielectric properties and antenna properties of $\mathrm{BiVO}_{4}$ ceramics. Compos. Part B Eng. 2019, 175, 107122. [CrossRef]

16. Joseph, N.; Varghese, J.; Teirikangas, M.; Sebastian, M.T.; Jantunen, H. Ultra-low sintering temperature ceramic composites of $\mathrm{CuMoO}_{4}$ through $\mathrm{Ag}_{2} \mathrm{O}$ addition for microwave applications. Compos. Part B Eng. 2018, 141, 214-220. [CrossRef]

17. Faouri, S.S.; Mostaed, A.; Dean, J.S.; Wang, D.; Sinclair, D.C.; Zhang, S.; Whittow, W.G.; Vardaxoglou, Y.; Reaney, I.M. High quality factor cold sintered $\mathrm{Li}_{2} \mathrm{MoO}_{4}-\mathrm{BaFe}_{12} \mathrm{O}_{19}$ composites for microwave applications. Acta Mater. 2019, 166, 202-207. [CrossRef]

18. Wang, D.; Zhang, S.; Wang, G.; Vardaxoglou, Y.; Whittow, W.; Cadman, D.; Zhou, D.; Song, K. Cold sintered CaTiO $-\mathrm{K}_{2} \mathrm{MoO}_{4}$ microwave dielectric ceramics for integrated microstrip patch antennas. Appl. Mater. Today 2020, 18, 100519. [CrossRef]

19. Dou, G.; Guo, M.; Li, Y.; Lin, J. The effect of LMBS glass on the microwave dielectric properties of the $\mathrm{Mg}_{3} \mathrm{~B}_{2} \mathrm{O}_{6}$ for $\mathrm{LTCC}_{\text {. J. Mater }}$ Sci. Mater. Electron. 2015, 26, 4207-4211. [CrossRef]

20. Zhou, D.; Pang, L.X.; Wang, D.W.; Qi, Z.M.; Reaney, I.M. High quality factor, ultralow sintering temperature $\mathrm{Li}_{6} \mathrm{~B}_{4} \mathrm{O}_{9}$ microwave dielectric ceramics with ultralow density for antenna substrates. ACS Sustain. Chem. Eng. 2018, 6, 11138-11143. [CrossRef]

21. Szwagierczak, D.; Synkiewicz-Musialska, B.; Kulawik, J.; Pałka, N. LTCC and Bulk $\mathrm{Zn}_{4} \mathrm{~B}_{6} \mathrm{O}_{13}-\mathrm{Zn}_{2} \mathrm{SiO}_{4}$ Composites for Submillimeter Wave Applications. Materials 2021, 14, 1014. [CrossRef]

22. Xi, J.; Shang, F.; Liu, F.; Xu, J.; Chen, G. A facile preparation of temperature-Stable borate ultra-low permittivity microwave ceramics for LTCC applicatons. Ceram. Int. 2020, 46, 19650-19653. [CrossRef]

23. Szwagierczak, D.; Synkiewicz-Musialska, B.; Kulawik, J.; Czerwińska, E.; Pałka, N.; Bajurko, P.R. Low temperature sintering of $\mathrm{Zn}_{4} \mathrm{~B}_{6} \mathrm{O}_{13}$ based substrates, their microstructure and dielectric properties up to the THz range. J. Alloys Compd. 2020, 819, 153025. [CrossRef]

24. Peng, R.; Li, Y.; Su, H.; Lu, Y.; Yun, Y.; Zhang, Q. A detailed study of the substitution mechanism for improved zinc-borate: High-performance and its crystal structure variation. J. Mater. Res. Technol. 2021, 12, 1360-1367. [CrossRef]

25. Martinez-Ripoll, M.; Martínez-Carrera, S.; García-Blanco, S. The crystal structure of copper metaborate, $\mathrm{CuB}_{2} \mathrm{O}_{4}$. Acta Cryst. 1971, 27, 677-681. [CrossRef]

26. Pisarev, R.V.; Boldyrev, K.N.; Popova, M.N.; Smirnov, A.N.; Davydov, V.Y.; Bezmaternykh, L.N.; Smirnov, M.B.; Kazimirov, V.Y. Lattice dynamics of piezoelectric copper metaborate $\mathrm{CuB}_{2} \mathrm{O}_{4}$. Phys. Rev. B 2013, 88, 024301. [CrossRef]

27. Imasaka, K.; Pisarev, R.V.; Bezmaternykh, L.N.; Shimura, T.; Kalashnikova, A.M.; Satoh, T. Excitation of multiple phonon modes in copper metaborate $\mathrm{CuB}_{2} \mathrm{O}_{4}$ via nonresonant impulsive stimulated Raman scattering. Phys. Rev. B 2018, 98, 054303. [CrossRef]

28. Molchanova, A.D.; Prosnikov, M.A.; Dubrovin, R.M.; Davydov, V.Y.; Smirnov, A.N.; Pisarev, R.V.; Boldyrev, K.N.; Popova, M.N. Lattice dynamics and electronic transitions in a structurally complex layered copper borate $\mathrm{Cu}_{3}\left(\mathrm{BO}_{3}\right)_{2}$. Phys. Rev. B 2017, 96, 174305. [CrossRef]

29. Mero, R.D.; Lai, C.H.; Du, C.H.; Liu, H.L. Spectroscopic signature of spin-charge-lattice coupling in CuB ${ }_{2} \mathrm{O}_{4}$. J. Phys. Chem. C 2021, 125, 4322-4329. [CrossRef]

30. Saito, M.; Taniguchi, K.; Arima, T.H. Gigantic optical magnetoelectric effect in $\mathrm{CuB}_{2} \mathrm{O}_{4}$. J. Phys. Soc. Jpn. 2008, 77, 013705. [CrossRef]

31. Petrakovskii, G.A.; Sablina, K.A.; Velikanov, D.A.; Vorotynov, A.M.; Volkov, N.V.; Bovina, A.F. Synthesis and magnetic properties of copper metaborate single crystals $\mathrm{CuB}_{2} \mathrm{O}_{4}$. Crystallogr. Rep. 2000, 45, 853-856. [CrossRef]

32. Pisarev, R.V.; Kalashnikova, A.M.; Schöps, O.; Bezmaternykh, L.N. Electronic transitions and genuine crystal-field parameters in copper metaborate $\mathrm{CuB}_{2} \mathrm{O}_{4}$. Phys. Rev. B 2011, 84, 075160. [CrossRef]

33. Kawamata, T.; Sugawara, N.; Haidar, S.M.; Adachi, T.; Noji, T.; Kudo, K.; Kobayashi, N.; Fujii, Y.; Kikuchi, H.; Chiba, M.; et al. Thermal conductivity and magnetic phase diagram of $\mathrm{CuB}_{2} \mathrm{O}_{4}$. J. Phys. Soc. Jpn. 2019, 88, 114708. [CrossRef]

34. Toyod, S.; Abe, N.; Arima, T. Gigantic directional asymmetry of luminescence in multiferroic CuB $\mathrm{O}_{4}$. Phys. Rev. B 2016, 93, 2011091. [CrossRef]

35. Sasaki, R.; Nii, Y.; Onose, Y. Surface acoustic wave coupled to magnetic resonance on a multiferroic CuB $\mathrm{O}_{4}$. Phys. Rev. B 2019, 99, 014418. [CrossRef]

36. Kudlacik, D.; Ivanov, V.Y.; Yakovlev, D.R.; Sapega, V.F.; Schindler, J.J.; Debus, J.; Bayer, M.; Pisarev, R.V. Exciton and excitonmagnon photoluminescence in the antiferromagnet $\mathrm{CuB}_{2} \mathrm{O}_{4}$. Phys. Rev. B 2020, 102, 035128. [CrossRef]

37. Ursu, D.; Dabici, A.; Miclau, M.; Miclau, N. Low-temperature hydrothermal synthesis of hierarchical flower-like $\mathrm{CuB}_{2} \mathrm{O}_{4}$ superstructures. Process. Appl. Ceram. 2020, 14, 113-118. [CrossRef]

38. Liu, J.; Wen, S.; Zou, X.; Feng, P. Visible-light-responsive copper(II) borate photocatalysts with intrinsic midgap states for water splitting. J. Mater. Chem. A 2013, 1, 1553-1556. [CrossRef] 
39. Luo, S.; Wang, F.; Yu, K.; Shao, J.; Peng, L.; Zeng, Q. Enhancement of visible-light photocatalytic activity of $\mathrm{Cu}_{3} \mathrm{~B}_{2} \mathrm{O}_{6}$ hybridized with $\mathrm{g}-\mathrm{C}_{3} \mathrm{~N}_{4}$. Coll. Surf. A 2017, 520, 409-419. [CrossRef]

40. Shannon, R.D. Dielectric polarizabilities of ions in oxides and fluorides. J. Appl. Phys. 1993, 73, 348-366. [CrossRef]

41. Qin, J.; Liu, Z.; Ma, M.; Li, Y. Machine learning approaches for permittivity prediction and rational design of microwave dielectric ceramics. J. Mater. 2021, Article in press. [CrossRef]

42. Kim, E.S.; Chun, B.S.; Freer, R.; Cernik, R.J. Effects of packing fraction and bond valence on microwave dielectric properties of $\mathrm{A}^{2+} \mathrm{B}^{6+} \mathrm{O}_{4}\left(\mathrm{~A}^{2+}: \mathrm{Ca}, \mathrm{Pb}, \mathrm{Ba} ; \mathrm{B}^{6+}: \mathrm{Mo}, \mathrm{W}\right)$ ceramics. J. Eur. Ceram. Soc. 2010, 30, 1731-1736. [CrossRef]

43. Li, J.; Han, Y.; Qiu, T.; Jin, C. Effect of bond valence on microwave dielectric properties of $(1-\mathrm{x}) \mathrm{CaTiO}_{3}-\mathrm{x}\left(\mathrm{Li}_{0.5} \mathrm{La}_{0.5}\right) \mathrm{TiO}_{3}$ ceramics. Mater. Res. Bull. 2012, 47, 2375-2379. [CrossRef]

44. Kamba, S.; Petzelt, J.; Buixaderas, E.; Haubrich, D.; Vanek, P.; Kuzel, P.; Jawahar, I.N.; Sebastian, M.T.; Mohanan, P. High frequency dielectric properties of $\mathrm{A}_{5} \mathrm{~B}_{4} \mathrm{O}_{15}$ microwave ceramics. J. Appl. Phys. 2001, 89, 3900-3906. [CrossRef]

45. Ma, M.; Wang, Y.; Navarro-Cia, M.; Liu, F.; Zhang, F.; Liu, Z.; Li, Y.; Hanham, S.M.; Hao, Z. The dielectric properties of some ceramic substrate materials at terahertz frequencies. J. Eur. Ceram. Soc. 2019, 39, 4424-4428. [CrossRef] 